\title{
Wpływ zjawisk społecznych na współczesny kryzys ekologiczny w świetle encykliki Laudato si'
}

\author{
Ryszard F. Sadowski \\ Wydział Filozofii Chrześcijańskiej \\ Uniwersytetu Kardynała Stefana Wyszyńskiego w Warszawie, \\ Instytut Ekologii i Bioetyki, ul. Wóycickiego 1/3, 01-938 Warszawa, r.sadowski@uksw.edu.pl
}

\begin{abstract}
Streszczenie
Encykliką Laudato si'. W trosce o wspólny dom papież Franciszek podsumowuje bogaty dorobek swoich poprzedników zawarty w wypowiedziach na temat kwestii ekologicznej. Stanowisko papieża Franciszka aktywnie włącza wspólnotę Kościoła katolickiego w główny nurt współczesnej debaty ekologicznej. Wydaje się, że spośród wielu zjawisk społecznych papież wskazuje na kilka, które mają szczególnie znaczący wpływ na współczesny kryzys ekologiczny. Do najważniejszych należy zaliczyć: więź między ubogimi a kruchością naszej planety, kulturę odrzucenia, nowy model postępu oraz nowy styl życia.
\end{abstract}

\section{Slowa kluczowe}

encyklika Laudato si', religia i ekologia, kultura odrzucenia, styl życia, model postępu

\section{Wprowadzenie}

Współcześnie coraz lepiej rozumiemy, że zjawiska społeczne wielorako wpływają zarówno na człowieka, jak i na środowisko. Są one badane w ramach tzw. kwestii społecznej, która jest żywo obecna w myśli europejskiej od kilku stuleci. Jednak pod koniec XIX wieku zyskała wyjątkowo szeroki wymiar. Stała się wówczas przedmiotem ożywionej refleksji zarówno uczonych, jak i Kościoła. Hanna Arendt uważa, że kwestia społeczna zaczęła odgrywać szczególnie ważną rolę dopiero w nowożytności. Wiele wskazuje na to, że stało się to ze względu na nowożytną zmianę sposobu podejścia do przyrody. Dobrze wyraża to myśl Francisa Bacona: „Wiedza i potęga ludzka to jedno i to samo, gdyż nieznajomość przyczyny pozbawia nas skutku. Nie można bowiem przyrody zwyciężyć inaczej niż przez to, że się jej słucha” (Bacon 1955: I, 3). Dzięki takiemu podejściu rozbudzono w szerokich masach społecznych nadzieję na powszechne przezwyciężenie trosk, chorób i biedy materialnej oraz na osiągnięcie dobrobytu jednostki i społeczeństwa (Łepko 2010: 122, Schäfer 1993). Do nowożytności nie kwestionowano bowiem przekonania, że powszechne ubóstwo jest wieczne i nieuniknione, ponieważ nie dostrzegano sposobu na jego przezwyciężenie. Panowała wówczas powszechna zgoda na to, że jedynie nielicznym dzięki szlachetnemu urodzeniu lub innym szczególnym okolicznościom 
udaje się wyzwolić z brzemienia ubóstwa (Arendt 2003: 23).

Dostrzeżenie szansy na powszechną zmia-nę położenia ubogich stało się powodem niepokojów społecznych, jakie obserwujemy w nowożytnej Europie. Hanna Arendt wskazuje, że od tego czasu kwestia społeczna stała się źródłem niemal wszystkich rewolucji, które stawiając sobie za cel przezwyciężenie ubóstwa, ostatecznie prowadziły jednak do jeszcze większych tragedii społecznych (Arendt 2003: 137-138). Przekonanie o tym, że ubóstwo jest głównym źródłem niepokojów społecznych, wyraził już F. Bacon, stwierdzając: „Rebelie brzucha bowiem są najgorsze" (Bacon 1959: 62).

Współcześnie wyrażenie „kwestia społeczna” stosowane jest głównie w obszarze nauk społecznych. Najczęściej określa się nim nabrzmiałe problemy społeczne, które prowadzą do dramatycznych sytuacji poszczególnych jednostek lub całych społeczności, uniemożliwiając zaspokojenie ich podstawowych potrzeb, co często skutkuje trwałym zaburzeniem porządku społecznego. Problemami tymi najczęściej są: bezrobocie, bezdomność, strukturalne ubóstwo, brak dostępu do opieki zdrowotnej i edukacji.

W proces refleksji nad kwestią społeczną mocno angażuje się Kościół katolicki, który zainspirowany nierównościami społecznymi już w 1891 roku encykliką Rerum novarum zainicjował powstanie społecznej nauki Kościoła. Od tego czasu kolejni papieże zabierali głos, wskazując na niepokojące zjawiska społeczne i wynikające stąd problemy oraz na konieczność i sposoby ich rozwiązania. Papieska Rada Iustita et Pax w 2005 roku wydała Kompendium nauki społecznej Kościoła, które systematyzuje dotychczasowe nauczanie Kościoła w sprawach społecznych. W dokumencie tym podkreśla się, że właściwe zrozumienie zachodzących współcześnie zjawisk społecznych domaga się całościowego ich ujmowania, ponieważ są one ze sobą „coraz bardziej powiązane, wzajemnie uzależnione i w coraz większym stopniu dotyczą całej rodziny ludzkiej" (Papieska Rada: 9).

W ostatnich dekadach społeczne nauczanie Kościoła wyraźnie łączy kwestię społeczną z różnymi przejawami kryzysu ekologicznego. Przywoływane tu Kompendium poświęca cały rozdział trosce o ochronę środowiska, wskazując na wzajemne powiązanie kwestii społecznej z kwestią ekologiczną (Papieska Rada: 451-487). Myśl tę rozwija papież Franciszek, który w encyklice Laudato si' wyraźnie łączy kwestię ekologiczną, będącą zasadniczym przedmiotem refleksji tego dokumentu, z niektórymi zjawiskami społecznymi, stanowiącymi wyraz tzw. kwestii społecznej.

Zasadniczym celem niniejszego opracowania jest analiza encykliki Laudato si' pod kątem wskazania wybranych zjawisk społecznych, które znacząco wpływają na kondycję ziemskiego ekosystemu. Wiele wskazuje na to, że do zjawisk tych należą: więź między ubogimi a kruchością naszej planety, kultura odrzucenia, nowy model postępu oraz nowy styl życia.

\section{Więź między ubogimi a kruchością naszej planety}

Przekonanie o ścisłej więzi łączącej niektóre zjawiska społeczne z kondycją ekosystemu Ziemi stanowi osnowę przesłania encykliki Laudato si. Społeczna nauka Kościoła już od wielu lat zwraca uwagę na to, że nie da się poszczególnych problemów globalnych rozwiązywać pojedynczo. Nadzieję daje jedynie łączne ich rozwiązywanie. Papież Franciszek przywołuje w tym kontekście słowa papieża Pawła VI, który wskazywał na powiązanie kryzysu ekologicznego z nierozważną i egoistyczną działalnością człowieka oraz zachęcał do autentycznego postępu społecznego i moralnego, który - jego zdaniem - jest kluczem do poprawy kondycji przyrody (LS: 4) ${ }^{1}$. Papież Benedykt XVI zaś zwracał uwagę, że błędem jest analizowanie wyzwań, wobec których staje dziś ludzkość,

$1 \mathrm{Na}$ oznaczenie encykliki Laudato si' będzie stosowany skrót LS. 
jedynie „na drodze wyizolowanego jednego tylko aspektu". Papież Franciszek przywołał także wypowiedź Benedykta XVI twierdzącego, że zarówno środowisko naturalne, jak i środowisko społeczne są pełne ran, które w istocie mają to samo źródło - błędne przekonanie o niczym nieskrępowanej wolności człowieka (LS: 6).

Wskazując na konieczność łącznego podejmowania niepokojących zjawisk społecznych i problemów ekologicznych, papież Franciszek przywołuje osobę św. Franciszka z Asyżu, który jest przykładem harmonijnej relacji człowieka z Bogiem, z innymi ludźmi, z przyrodą i z samym sobą. Ten wyjątkowy święty pokazał bowiem, do jakiego stopnia nierozerwalne jest połaczenie troski o przyrodę z troską o ubogich (LS: 10).

Przedstawiając skalę współczesnych wyzwań społecznych i środowiskowych, papież wyraża opinię, że „[...] nie jest możliwe znalezienie właściwej odpowiedzi na każdy problem z osobna. Fundamentalne znaczenie ma poszukiwanie rozwiązań integralnych, uwzględniających interakcje systemów przyrodniczych między sobą oraz z systemami społecznymi. Nie ma dwóch odrębnych kryzysów - jednego środowiskowego, a drugiego społecznego - ale istnieje jeden złożony kryzys społeczno-ekologiczny. Wytyczne dotyczące rozwiązania wymagają zintegrowanego podejścia do walki z ubóstwem, aby przywrócić godność wykluczonym i jednocześnie zatroszczyć się o naturę" (LS: 139).

Papież przestrzega także przed ułudą rozwiązywania problemów środowiskowych za pomocą samej tylko technologii i finansów. Jego zdaniem działania takie nie są bowiem w stanie dostrzec różnorodnych i wielorako uwarunkowanych powiązań między procesami zachodzącymi w społeczeństwie i przyrodzie. W konsekwencji jednostronne, techniczne rozwiązania pojedynczych problemów przyczyniają się do powstania kolejnych problemów, często jeszcze bardziej niebezpiecznych (LS: 20).

Ścisły związek pomiędzy kryzysem ekologicznym i kryzysem społecznym jest zdaniem papieża Franciszka szczególnie wyraźnie widoczny w zachodzących zmianach klimatycznych. Następstwa tych zmian obserwujemy bowiem na płaszczyźnie ekologicznej, społecznej, ekonomicznej i politycznej. Jednak wobec największych wyzwań wynikających ze zmian klimatycznych stają najubożsi, których środki utrzymania w największym stopniu są uzależnione od zasobów środowiskowych. Zmiany klimatyczne zakłócają równowagę ekosystemów i prowadzą zamieszkujących je ubogich do utraty środków do życia oraz zmuszają ich do masowych migracji, co nastręcza kolejnych problemów społecznych, politycznych i środowiskowych (LS: 24-25, 31).

Pomimo wielkich niebezpieczeństw, na jakie narażona jest dziś ludzkość, papież Franciszek jest zdania, że wciąż mamy szansę na ich zażegnanie i przywrócenie harmonii w świecie. Wyraża on przekonanie, że ludzkość jest zdolna do współpracy w trosce o wspólny dom. Papież zachęca jednak do większej konsekwencji w działaniach. Nie można bowiem mówić o budowaniu lepszej przyszłości, jeśli pomija się kwestię kryzysu ekologicznego i cierpienia ubogich zepchniętych na margines społeczeństwa (LS: 13).

\section{Kultura odrzucenia}

Kolejnym ważnym zjawiskiem społecznym, które papież Franciszek łączy z kwestią ekologiczną, jest „kultura odrzucenia”. Jego zdaniem jest ona w znacznej mierze przyczyną złej kondycji naszej planety. Kultura ta dotyka zarówno ludzi, jak i przedmiotów, z których współcześnie coraz łatwiej rezygnujemy, czyniąc je tym samym zbędnymi odpadami. Papież, charakteryzując dominującą współcześnie na Zachodzie kulturę odrzucenia, odwołuje się do przyrody i wskazuje, że w przyrodzie nie ma niczego niepotrzebnego. Funkcjonowanie ekosystemów zakłada zamknięty cykl, mianowicie: „rośliny syntetyzują składniki odżywcze, które stają się karmą roślinożerców. Te z kolei stają się pokarmem zwierząt mięsożernych, zapewniających znaczne ilości odpadów organicznych, 
które dają początek nowej generacji roślin" (LS: 22).

Papież wskazuje, że kultura odrzucenia przejawia się szczególnie wyraźnie w mentalności społeczeństw państw rozwiniętych, w których użyteczność stanowi główne kryterium postrzegania przydatności rzeczy i osób. Stąd wskutek utraty określonych zdolności bądź właściwości rezygnuje się z nich. Objawia się to w różnoraki sposób. Najwyraźniej widać to na przykładzie dóbr materialnych, kiedy bogaci przedstawiciele Zachodu pozbywają się zupełnie dobrych produktów tylko dlatego, że pojawiły się na rynku ich nowsze wersje. Kultura odrzucenia, charakteryzująca się logiką „użyj i wyrzuć”, nie ogranicza się jednak tylko do przedmiotów. Jej przejawy łatwo dostrzec także w relacjach międzyludzkich, choćby w przypadku osób, które nie są w stanie wypełniać określonych zadań - zatem nie wpisują się w mentalność zysku ekonomicznego i sukcesu życiowego. Dotyczy to głównie ludzi starych i dzieci, które z różnych względów nie spełniają oczekiwań (LS: 123). Konrad Lorenz już w latach 70. XX wieku opisał to zjawisko, wskazując, że jest ono jednym z grzechów śmiertelnych cywilizowanej ludzkości (Lorenz 1973: 40-41).

Zdaniem papieża Franciszka postęp, jaki się dokonał w ciągu ostatnich dwustu lat, wprawdzie znacznie przyczynił się do rozwoju gospodarczego, ale destrukcyjnie wpłynął na rozwój społeczny. Postęp ten bowiem niejednokrotnie skutkuje wykluczeniem społecznym, dezintegracją i zerwaniem więzi międzyludzkich (LS: 46). Zjawisko to przybiera różne formy. Niepokojące są przejawy ekologicznej dyskryminacji ubogich w dostępie do obszarów o szczególnym pięknie przyrodniczym. Sztucznie wydziela się bowiem tereny, na które wstęp mają jedynie uprzywilejowane warstwy społeczne (LS: 45). Papież zwraca też uwagę, że liczba ludzi wykluczonych stale rośnie i stanowią oni obecnie większość ludzkości. Ich problemy są często traktowane jako „negatywny efekt uboczny" procesów zachodzących w światowej gospodarce. Politycy, eksperci i przedstawiciele mediów często marginalizują problemy osób wykluczonych i nie podejmują konkretnych działań w celu ich przezwyciężenia. Dzieje się tak - jak stwierdza papież - ponieważ warstwy uprzywilejowane nie mają bezpośredniego kontaktu z wykluczonymi, którzy są pozostawieni samym sobie. Osoby, które mają wpływ na losy świata, nie dostrzegają problemów ubogich, gdyż żyją w luksusowych warunkach w izolowanych obszarach miejskich, gdzie wykluczeni nie mają wstępu. Zdaniem papieża „brak fizycznego kontaktu i spotkania [...] sprzyja znieczulaniu sumień i ignorowaniu części rzeczywistości w stronniczych analizach" (LS: 49).

Wydaje się, że kultura odrzucenia jest konsekwencją egoizmu, który rodzi strach przed koniecznością podzielenia się z ubogimi. Jest to - zdaniem papieża - spowodowane kryzysem więzi rodzinnych i społecznych oraz postmodernistyczną mentalnością indywidualistyczną, która koncentruje człowieka na działaniach prowadzących do natychmiastowej satysfakcji. Coraz częściej przecież mamy dziś do czynienia z krótkowzrocznym konsumpcjonizmem, który przejawia się troską jedynie o siebie i niezauważaniem potrzeb innych. Papież Franciszek wyraźnie wskazuje, że tymi innymi są zarówno współcześni wykluczeni, jak i wykluczeni przyszłości. Podkreśla więc pilną konieczność moralną nowej solidarności wewnątrzpokoleniowej oraz lojalnej solidarności międzypokoleniowej (LS: 162).

Papież, mówiąc o solidarności z wykluczonymi, nie ogranicza się jedynie do ludzi. Zalecana przez niego postawa otwartości serca prowadzi bowiem do powszechnej komunii, z której nic nie jest wykluczone. Stwierdza wręcz, że „nie możemy uważać siebie za osoby naprawdę miłujące, jeśli wykluczamy z naszych zainteresowań jakąś część rzeczywistości”. Zdaniem papieża obojętność i okrucieństwo człowieka wobec innych stworzeń prowadzi także do okrucieństwa i obojętności wobec człowieka (LS: 92). Papież Franciszek wskazuje w ten sposób, że kultura wykluczenia dotyka tak ludzi, jak 
i przyrodę i to w perspektywie zarówno teraźniejszości, jak i przyszłości.

Zachęcając do budowania kultury komunii i otwartości, papież przypomina, że w tradycji chrześcijańskiej nigdy nie uznawano prawa do własności prywatnej za absolutne i nienaruszalne. Przywołując słowa Jana Pawła II, papież Franciszek podkreśla konieczność dzielenia się bogatych z wykluczonymi: „[...] nie jest zgodne z planem Bożym, by rozporządzać tym darem tak, że z jego dobrodziejstw korzystaliby jedynie nieliczni" (Jan Paweł II 2009: 416). W encyklice Centesimus annus zaś polski papież stwierdza, że zasoby naszej planety nie moga być zawłaszczane przez nielicznych: „Bóg dał ziemię całemu rodzajowi ludzkiemu, aby utrzymywała wszystkich jego członków, nie wykluczając ani nie wyróżniając nikogo" (Jan Paweł II 1991: 31).

Papież Franciszek, mówiąc o konieczności odejścia od kultury odrzucenia i budowania kultury komunii, podkreśla, że człowiek jest częścią przyrody i wraz z nią tworzy wspólnotę życia zamieszkującą Ziemię. A wszystkich członków tej wspólnoty winny łączyć więzi braterstwa, do których zachęca nas św. Franciszek z Asyżu. Przezwyciężenie podziałów i marginalizacji najsłabszych, tzn. współczesnych i przyszłych ubogich oraz przyrody, będzie możliwe tylko dzięki zintegrowanemu podejściu do walki z ubóstwem, przywróceniu godności wykluczonym oraz trosce o przyrodę (LS: 139). Zadanie to jest o tyle trudne, że współczesna kultura prowadzi nie tylko do atomizacji społeczeństwa, marginalizacji ubogich i egoistycznej eksploatacji przyrody, ale także do wykluczenia Boga, którego miejsce zajmuje ludzkie ego. Problemu tego nie rozwiąże prawo ani programy polityczne, potrzebny jest bowiem powrót do podstawowych zasad i prawdy obiektywnej. Nadzieję na uporządkowanie wzajemnych relacji wszystkich mieszkańców Ziemi - naszego wspólnego domu, daje przemiana wewnętrzna człowieka i wypracowanie postawy otwartości na innych w oparciu o zdrową pokorę i radosną wstrzemięźliwość (LS: 224, 123).

\section{Nowy model postępu}

Kolejnym zagadnieniem społecznym, które zdaniem papieża Franciszka ściśle łączy się z kwestią ekologiczną, jest model postępu. Kościół od kilku dekad podejmuje refleksję nad postępem. Jednym z pierwszych dokumentów kościelnych poświęconych wprost postępowi jest encyklika Populorum progressio, w której papież Paweł VI mówił o potrzebie pełnego rozwoju poszczególnych ludzi oraz ogólnego postępu ludzkiej społeczności (Paweł VI 1967: 5). Już wówczas papież zwracał uwagę na to, że rozwój nie może ograniczać się jedynie do postępu gospodarczego. Tylko postęp przyczyniający się do rozwoju „każdego człowieka i całego człowieka" można nazwać postępem prawdziwym i zupełnym (Paweł VI 1967: 14). Papież wskazywał też, że „[...] gdy mówimy o rozwoju, wyrażamy troskę i o postęp społeczny, i o wzrost gospodarczy. Nie wystarczy jednak zwiększenie wspólnych zasobów, by nastąpił sprawiedliwy ich podział; nie wystarczy postęp techniczny, aby ziemia stawszy się jakby bardziej ludzką - nadawała się lepiej do zamieszkania" (Paweł VI 1967: 34). Zdaniem Pawła VI postępowi ekonomicznemu i technicznemu musi towarzyszyć postęp moralny, który prowadzi do rozwoju wartości duchowych.

Papież Franciszek w encyklice Laudato si', nawiązując do nauczania swoich poprzedników, łączy współczesny kryzys ekologiczny z negatywnymi konsekwencjami wzrostu gospodarczego i przestrzega, że „najbardziej niezwykłe postępy naukowe, najbardziej niesamowite osiągnięcia techniczne, najcudowniejszy rozwój gospodarczy, jeśli nie łączą się z autentycznym postępem społecznym i moralnym, w ostatecznym rachunku zwracają się przeciw człowiekowi” (Paweł VI 1970: 4). Papież Franciszek podkreśla też, że prawdziwy rozwój ma charakter moralny, cechuje się poszanowaniem osoby ludzkiej i uwzględnia świat przyrody, bierze bowiem pod uwagę naturę wszystkich bytów i ich wzajemne powiązanie w uporządkowany system. Ponadto wskazuje na potrzebę skorygowania współczesnych modeli rozwoju, 
które nie zapewniają poszanowania środowiska naturalnego (LS: 5, 6). Zdaniem Franciszka ochrona Ziemi - naszego wspólnego domu - powinna obejmować troskę o zjednoczenie całej rodziny ludzkiej w jej aspiracjach do rozwoju zrównoważonego i zintegrowanego (LS: 13).

Wskazując na potrzebę wypracowania nowego modelu rozwoju, papież zwraca uwagę na niezwykły postęp techniczny, jaki dokonał się w ciągu ostatnich lat, którego dobrą ilustracją jest dynamiczny rozwój świata cyfrowego i komunikacji międzyludzkiej. Papież zauważa jednak, że nowe możliwości techniczne skutkują informacyjnym zgiełkiem i nie prowadzą do mądrego życia, głębokiego myślenia i wielkodusznego miłowania. Niezbędne wydaje się dążenie do tego, żeby środki nowoczesnej komunikacji nie przyczyniały się do degradacji kultury, ale były bodźcem do nowego rozwoju kulturalnego ludzkości. Papież, mówiąc o właściwym modelu rozwoju, zwraca też uwagę, że musi on prowadzić do autentycznego rozwoju ludzkiego i przestrzega, że nowe środki komunikacji zamiast zbliżać ludzi, często prowadzą do selekcjonowania lub eliminowania relacji między osobami ze względu na zamęt spowodowany przesytem tych relacji. To zaś prowadzi do „sztucznych emocji”, które osłabiają więź człowieka z drugim człowiekiem i z przyrodą (LS: 47).

Papież Franciszek podkreśla także rolę religii w dochodzeniu do "pełnego rozwoju ludzkości” (LS: 62). Otwarcie się na Boga zmienia bowiem sposób postrzegania świata i jego rozwoju. Wiara umożliwia człowiekowi dostrzeżenie znaczenia i tajemniczego piękna świata (LS: 70). Ponadto Bóg, stwarzając człowieka, zleca mu troskę o świat i jego rozwój (LS: 124). Człowiek nie jest jednak w stanie wypełnić tego zadania, przyjmując „taki model rozwoju, który by nie szanował i nie popierał praw ludzkich, osobistych i społecznych, ekonomicznych i politycznych, łącznie z prawami narodów i ludów" - taki rozwój nie byłby godny człowieka (LS: 93; Jan Paweł II 1989: 33).
Prezentując nowy model postępu, papież Franciszek odwołuje się do tradycji chrześcijańskiej, która proponuje współczesnej kulturze konsumpcyjnej alternatywny sposób rozumienia jakości życia. Niepohamowana konsumpcja i kultura użycia nie są przecież w stanie zaspokoić aspiracji serca człowieka i wypełnić ludzkiej egzystencji sensem i radością (LS: 209). Papież wskazuje na ważną rolę, jaką odgrywają wartości duchowe, autentyczna radość i odejście od obsesji posiadania oraz konsumpcji. Podobnie kwestię ludzkiego życia ujmuje wiele tradycji religijnych. Ponieważ pęd do nieograniczonej konsumpcji zakłóca wewnętrzną harmonię człowieka, więc „powrót do prostoty, która pozwala nam się zatrzymać i docenić to, co małe, i dziękować za możliwości, jakie daje życie, nie przywiązując się do nich ani nie smucąc z powodu tego, czego nie posiadamy", pozwala wyzwolić się z pragnienia panowania i gromadzenia (LS: 222).

Jak twierdzi papież Franciszek, współczesny człowiek zdaje się utożsamiać postęp ze wzrostem swoich możliwości, które zapewniają mu dobrobyt oraz poczucie bezpieczeństwa i wartości. Nie zauważa, że dobro i prawda nie zależą od możliwości technicznych i zasobów ekonomicznych. Problem bierze się stąd, że dzisiejszy człowiek nie został wychowany do właściwego posługiwania się dostępnymi mu nowoczesnymi środkami. Dzieje się tak, ponieważ dynamicznemu rozwojowi technicznemu nie towarzyszył równoległy rozwój istoty ludzkiej pod względem odpowiedzialności, wartości i sumienia. Autentyczny rozwój jest dziś zagrożony przez człowieka, który dążąc do osiągnięcia krótkowzrocznych korzyści, często niewłaściwie korzysta ze swoich ogromnych możliwości (LS: 105).

Zwolennicy poglądu redukującego postęp jedynie do wymiaru ekonomicznego nie uwzględniają właściwego poziomu produkcji dóbr, lepszej dystrybucji bogactw, troski o przyrodę i praw przyszłych pokoleń. Koncentrują się zaś na maksymalizacji zysku. Prowadzi to zdaniem papieża do rozrzutnego i konsumpcyjnego „nadrozwoju”, który 
w żaden sposób nie zwalcza przejawów odbierania człowiekowi jego ludzkiej godności. Jeśli rozwój mierzony jest wyłącznie kategoriami zysku, zapomina się o najbardziej bezbronnych, nie zabezpiecza ich podstawowych potrzeb poprzez adekwatne programy socjalne i instytucje ekonomiczne (LS: 109). Autentyczny rozwój nie może się ograniczać tylko do dostarczenia środków niezbędnych do życia. Integralna troska o rozwój „całego człowieka i każdego człowieka" domaga się bowiem stworzenia takich warunków, aby człowiek mógł pracować. Praca jest przecież konieczna w dojrzewaniu i rozwoju człowieka, nadaje (przynajmniej częściowo) sens ludzkiemu życiu i prowadzi do osobistego spełnienia (LS: 128).

Właściwy model rozwoju musi także uwzględniać ochronę środowiska, która powinna być integralnym elementem procesu rozwoju (LS: 141). Papież wskazuje, że „aby można było mówić o prawdziwym rozwoju, trzeba się upewnić, czy dochodzi do integralnej poprawy jakości ludzkiego życia, co wiąże się z analizą przestrzeni, na której żyją ludzie". Środowisko, w którym człowiek żyje, wpływa bowiem na jego sposób patrzenia na życie, odczuwania i działania (LS: 147). Zdaniem papieża ważnym czynnikiem właściwego rozwoju jest przezwyciężenie mentalności odrzucenia i nieufności oraz wypracowanie kultury komunii, która integruje osoby niekiedy znacznie różniące się od siebie. Sprzyja temu tworzenie przestrzeni architektonicznych, które dają możliwość nawiązywania relacji między tymi ludźmi, a przez to pomagają uznać drugiego za osobę ludzką (LS: 152).

Innym ważnym czynnikiem nowego modelu rozwoju jest solidarność międzypokoleniowa, która odchodzi od mierzenia rozwoju jedynie w perspektywie krótkowzrocznej korzyści, a wpisuje się w logikę bezinteresownego daru dla przyszłych mieszkańców naszej planety (LS: 159, 162). Dla papieża nie pozostawia wątpliwości, że nowe modele rozwoju muszą stawiać na pierwszym miejscu interesy ludzkich mieszkańców Ziemi. Przywołuje w tym kontekście pierwszą zasadę Deklaracji z Rio de Janeiro (1992), która głosi, że „istoty ludzkie są w centrum zainteresowania $\mathrm{w}$ procesie zrównoważonego rozwoju" (LS: 167).

Papież Franciszek podkreśla też realistyczność nowych modeli rozwoju i wskazuje, że nie są one wymierzone w postęp i rozwój człowieka. Papież docenia rozwój technologiczny oraz jego wkład w przezwyciężanie ludzkich nieszczęść, szczególnie dzięki medycynie, inżynierii i komunikacji (LS: 102). Zwraca jednak uwagę na to, że ograniczenie i spowolnienie tempa produkcji i konsumpcji może doprowadzić do innego rodzaju postępu i rozwoju. Zrównoważone korzystanie z zasobów naturalnych może być inwestycją, która przynosi ekonomiczne korzyści. Wprowadzenie bardziej innowacyjnej produkcji, która w mniejszym stopniu oddziałuje na środowisko, w żaden sposób nie musi ograniczać ludzkiej kreatywności i marzeń o postępie, a jedynie nadaje tym marzeniom nowy kierunek (LS: 191).

Warunkiem wypracowania nowych modeli postępu jest dokonanie refleksji nad sensem gospodarki i jej celami, co umożliwi przeprowadzenie koniecznych korekt wadliwych mechanizmów rządzących gospodarką oraz przekształcenie modelu globalnego rozwoju. Papież podkreśla, że zmiana modelu rozwoju musi być radykalna, gdyż za pomocą półśrodków nie przezwycięży się kryzysu ekologicznego, a jedynie odsunie w czasie nadejście nieuchronnego kataklizmu. Postęp musi być przedefiniowany. Franciszek wskazuje kryteria, których spełnienie zapewni autentyczny postęp. „Rozwój technologiczny i gospodarczy, który nie pozostawia świata lepszym, a jakości życia integralnie wyższej, nie może być uznany za postęp" (LS: 194).

Analizując współczesną debatę nad właściwym modelem postępu, papież Franciszek wskazuje na dwa przeciwstawne obozy. Z jednej strony znajdują się ci, którzy nie uwzględniają wymiaru etycznego postępu i odrzucają możliwość dokonania radykalnych zmian, podtrzymują zaś mit nieograniczonego postępu i twierdzą, że problemy środowiskowe mogą być rozwiązane dzięki 
zastosowaniu nowych technologii. Z drugiej zaś strony znajdują się ci, którzy twierdzą, że rodzaj ludzki stanowi główne zagrożenie dla ziemskiego ekosystemu, dlatego trzeba ograniczyć jego obecność na naszej planecie i powstrzymać go od wszelkich ingerencji w środowisko. Zdaniem papieża żadne z tych stanowisk nie zwiększa szans na wypracowanie modelu autentycznego rozwoju. Tylko otwarty i uczciwy dialog pomiędzy zwolennikami obu stanowisk uprawdopodabnia wypracowanie rozwiązań, które dadzą nadzieję na optymistyczną wizję naszej planety. (LS: 6o).

Nadzieję na znalezienie właściwego rozstrzygnięcia tego dramatycznego sporu papież dostrzega w edukacji ekologicznej. Uważa, że nie może się ona ograniczać jedynie do informacji naukowej oraz budzenia świadomości zagrożeń środowiskowych i możliwości ich przezwyciężenia. Edukacja ekologiczna powinna uwzględniać krytykę „mitów” nowoczesności opartej na indywidualizmie, nieograniczonym postępie, konkurencji, konsumpcjonizmie oraz rynku bez zasad. Edukacja taka powinna także prowadzić - zdaniem papieża - do przywrócenia równowagi ekologicznej człowieka między samym sobą a drugim człowiekiem, równowagi między człowiekiem a przyrodą, a ostatecznie także do równowagi człowieka z Bogiem. Niezbędnym elementem nowej edukacji ekologicznej powinna być etyka ekologiczna, która skutecznie wychowa ludzkość do solidarności, odpowiedzialności i troski opartej na współczuciu (LS: 210).

Pomoc w skutecznym wprowadzaniu nowych modeli rozwoju - zdaniem papieża - stanowi także miłość społeczna, która zgodnie ze społeczną nauką Kościoła jest kluczem do prawdziwego rozwoju. Miłość ta przejawia się w budowaniu społeczeństwa bardziej ludzkiego i bardziej godnego osoby. Powinna ona być realizowana na płaszczyznach: politycznej, ekonomicznej oraz kulturowej, a także powinna być najważniejszą normą działania. Miłość społeczna realizuje się zarówno w codziennych gestach życzliwości, jak i w wypracowywaniu wielkich strategii ochrony przyrody oraz tworzeniu „kultury troski”, która ogarniałaby całą ludzkość (LS: 231).

\section{Nowy styl życia}

Zmiana dotychczasowego stylu życia stanowi kolejne ważne zjawisko społeczne, które przewija się w całej encyklice Laudato $S i$ 'jako fundamentalny element strategii w walce $z$ narastającym kryzysem ekologicznym. Podobnie jak w przypadku innych omawianych zjawisk społecznych, papież Franciszek nawiązuje w tej kwestii do nauczania swoich poprzedników. Za Janem Pawłem II przypomina, że troska o świat wymaga radykalnej zmiany stylu życia, modeli produkcji oraz konsumpcji. Tylko wprowadzając prawdziwą „ekologię ludzką”, możemy chronić środowisko (LS: 5, Jan Paweł II 1991: 58).

Franciszek, odwołując się do niepokojących przejawów kryzysu ekologicznego, a zwłaszcza do zmian klimatycznych, które skutkują wzrostem ekstremalnych zjawisk pogodowych i podnoszeniem się poziomu mórz, wzywa ludzkość do zmiany stylu życia. Zmiana taka może bowiem powstrzymać globalne ocieplenie, a przynajmniej zmniejszyć jego przyczyny wynikające z działalności człowieka (LS: 23). Ponadto papież wskazuje na wysokie tempo spożycia i produkcji odpadów oraz zmiany środowiskowe, które przekraczają możliwości naszej planety, uniemożliwiając utrzymanie dotychczasowego stylu życia. Ostrzega, że jeśli radykalnie nie zmienimy stylu naszej obecności w świecie, to doprowadzimy do niechybnej katastrofy (LS: 161).

Apelując do wszystkich ludzi dobrej woli, Franciszek przestrzega przed bagatelizowaniem zagrożeń i podkreśla, że nasza planeta znajduje się w realnym niebezpieczeństwie, które nasila się w miarę utrwalania się konsumpcyjnego i egoistycznego stylu życia (LS: 59). Styl ten - zdaniem papieża - jest konsekwencją redukcjonizmu godzącego w życie ludzkie i społeczeństwo, zawęża je bowiem do wymiaru materialnego, zubażając wymiar duchowy i etyczny życia jednostek i społeczeństw (LS: 107). Papież udziela 
też przestrogi przed bezkrytyczną zgodą na dominację paradygmatu technokratycznego, prowadzącego do uznania za antykulturowe tych stylów życia, których cele chociażby w części „mogły być niezależne od techniki, jej kosztów oraz jej globalizującej i umasawiającej władzy" (LS: 108). Zdaniem papieża nowy styl życia powinien być konsekwencją przemyślanych, zsynchronizowanych i wszechstronnych odpowiedzi na kryzys ekologiczny, które będą wynikiem powszechnego przyjęcia kultury ekologicznej występującej przeciw ekspansji paradygmatu technokratycznego. W przeciwnym razie grozi nam niebezpieczeństwo niedostrzeżenia rzeczywistych źródeł obecnego kryzysu i ułuda poszukiwania sposobów jego przezwyciężenia jedynie za pomocą środków technicznych (LS: 111).

Piętnując współczesny indywidualizm i skupianie się na sobie, papież krytykuje „wypaczony antropocentryzm”, który prowadzi do „wypaczonego stylu życia”. Styl ten jest bowiem skutkiem mentalności przyznawania absolutnego priorytetu temu, co jest doraźnie wygodne i relatywizowania wszystkiego innego (LS: 122). Franciszek podkreśla, że przełamanie takich postaw jest możliwe dzięki „wychodzeniu ku innym”. Ponieważ tylko wówczas człowiek rozpoznaje wartości właściwe innym stworzeniom, jest zdolny do troski o potrzeby innych i staje się zdolny do samoograniczenia. Odejście od egoistycznej samotności i nawiązanie bliskich więzi jest podstawą wszelkiej troski o innych zarówno o ludzi, jak i o przyrodę. Odrzucenie indywidualizmu wzbudza nadzieję na wypracowanie alternatywnego stylu życia i umożliwia dokonanie realnych przemian w społeczeństwie (LS: 208). Ponadto papież podkreśla, że warunkiem koniecznym zmiany aktualnego stylu życia jest powrót do świadomości wspólnoty, którą tworzą wszyscy mieszkańcy naszej planety. Wspólnota ta staje dziś wobec wspólnych wyzwań, a ostatecznie będzie w przyszłości dzielić wspólny los (LS: 202).

Analizując przyczyny przyjęcia obecnego, destrukcyjnego stylu życia, papież
Franciszek zwraca uwagę, że konsekwencją akceptacji paradygmatu technokratycznego jest kompulsywny konsumpcjonizm, który sprawia, że człowiek czuje się wolny tak długo, jak długo jest w stanie konsumować. W rzeczywistości jednak wolni są tylko ci, którzy należą do uprzywilejowanych grup, posiadających wpływy ekonomiczne i zasoby finansowe (LS: 203). Zjawisko to utrwala wśród ludzi egoizm, zwiększa ich zachłanność, a ostatecznie prowadzi do izolacji i samotności. Papież jest przekonany, że im bardziej człowiek jest ubogi duchowo, tym bardziej potrzebuje rzeczy, które może kupować i konsumować. Człowiek taki jest niezdolny do samoograniczenia i respektowania dobra wspólnego. Przyjmuje on normy moralne tylko w takim zakresie, w jakim pozwalają mu realizować jego własne potrzeby. Wszystko to prowadzi do kryzysu społecznego, który na równi z kryzysem środowiskowym może przyczynić się do przemocy i zniszczenia (LS: 204).

Powszechna zmiana stylu życia daje nadzieję na wywarcie skutecznej presji na kierujących państwami i nadających ton rozwojowi gospodarczemu i społecznemu. Potwierdzają to doświadczenia ruchów konsumenckich, którym wielokrotnie udawało się z powodzeniem przekonywać do nabywania lub powstrzymywania się od zakupu określonych produktów. W ten sposób wymuszano na wielu przedsiębiorstwach zmianę strategii produkcji ze względu na oddziaływanie na środowisko. Papież Franciszek podkreśla znaczenie tego typu inicjatyw w kształtowaniu prośrodowiskowych nawyków konsumenckich i przywołuje słowa Benedykta XVI, który mówił wprost o odpowiedzialności konsumentów i wpływie konsumpcji na degradację środowiska: „Kupno jest zawsze aktem moralnym, nie tylko ekonomicznym" (LS: 206, Benedykt XVI 2009: 66).

Edukacja jest kolejnym ważnym czynnikiem wpływającym na zmianę stylu życia. Jednak - zdaniem papieża - spełni ona swą rolę w budzeniu „obywatelskiego zaangażowania ekologicznego” tylko wówczas, gdy 
nie będzie ograniczać się do informowania, ale skoncentruje się na moralnym doskonaleniu człowieka. Wychowany w ten sposób człowiek będzie zdolny do odpowiedzialności za środowisko naturalne poprzez podjęcie określonych działań: zaniechanie używania tworzyw sztucznych, zmniejszenie zużycia wody, oszczędzanie energii elektrycznej, segregowanie odpadów, szacunek do istot żywych, korzystanie z transportu publicznego, zalesianie itp. Właściwa edukacja może sprawić, że wszystkie te działania będą konsekwencją głębokich motywacji wynikających z miłości do drugiego człowieka i do przyrody (LS: 211).

Ponadto papież wskazuje na wielkie znaczenie religii w budzeniu głębokich motywacji. Tradycje religijne formują swych wiernych do pogłębiania rozwoju duchowego oraz dawania pierwszeństwa „być” przed „mieć”. Franciszek jest zdania, że rozwój duchowy pomaga człowiekowi wyzwalać się z kompulsywnej konsumpcji oraz prowadzi go do „radosnej celebracji życia”. Natomiast obsesyjna konsumpcja zakłóca pokój serca i odbiera poczucie życiowego spełnienia. Papież wskazuje pod tym względem na duchowość chrześcijańską, która zawsze promowała wstrzemięźliwość i duchowy wymiar rozwoju człowieka, podkreśla jednak, że elementy te są obecne także w wielu innych tradycjach religijnych (LS: 222, 207). Rozwój duchowy człowieka wychodzi bowiem naprzeciw osiągnięciu pokoju ducha, który wydaje się możliwy jedynie wówczas, gdy człowiek porzuci styl życia nacechowany pośpiechem, hałasem, niepokojem i byciem nieustannie zajętym. Ponieważ taki styl życia prowadzi - zdaniem papieża - do „kultu powierzchowności” (LS: 225).

\section{Zakończenie}

Encyklika Laudato si' jest pierwszym tak wysokiej rangi dokumentem Kościoła katolickiego, który w całości poświęcony jest kwestii ekologicznej. Wpisuje się tym samym w bogatą spuściznę społecznej nauki Kościoła, która od ponad stu dwudziestu lat identyfikuje oraz wskazuje rozwiązania problemów, przed jakimi staje cała rodzina ludzka. Papież Franciszek stwierdza: „w obliczu globalnej degradacji środowiska, chciałbym zwrócić się do każdej osoby mieszkającej na tej planecie. [...] W tej encyklice proponuję nawiązanie dialogu ze wszystkimi w odniesieniu do naszego wspólnego domu" (LS: 3). Apel papieża jest podyktowany dramatycznym położeniem, w jakim znalazła się ludzkość i cała nasza planeta. Tylko mobilizacja wszystkich ludzi dobrej woli niesie nadzieję na przezwyciężenie śmiertelnie niebezpiecznego kryzysu, wobec którego obecnie stoimy.

Papież Franciszek przestrzega w swym przesłaniu przed jednostronnymi i uproszczonymi diagnozami kryzysu ekologicznego oraz działaniami, które stwarzają jedynie pozory rozwiązań, uspokajając opinię publiczną na świecie i sprawiając wrażenie, że ludzkość już podjęła konieczne działania, pozwalające zażegnać grożące nam niebezpieczeństwo. Franciszek wskazuje na złożoność i wielorakie uwarunkowania procesów zachodzących w życiu społecznym i w przyrodzie. Zdaniem papieża nadzieję na skuteczną walkę z kryzysem ekologicznym daje tylko odpowiedź integralna, która będzie jednocześnie uwzględniała kwestię przyrodniczą, społeczną i ekonomiczną.

Powyższe opracowanie miało na celu analizę encykliki pod kątem wskazania tych zjawisk społecznych, które w największym stopniu przyczyniają się do degradacji naszej planety. Wiele wskazuje na to, że zmiana w podejściu do tych zjawisk wzbudza jednocześnie największą nadzieję na polepszenie kondycji naszej planety. Do zjawisk tych należy zaliczyć więź między ubogimi a kruchością naszej planety, kulturę odrzucenia, nowy model postępu oraz nowy styl życia.

Zdaniem papieża ludzkość jest zdolna do dokonania koniecznych zmian. Niezbędne jest jednak przywrócenie bliskich więzi ludzi między sobą i między ludźmi a przyrodą oraz wypracowanie kultury komunii, która położy tamę egoistycznemu i krótkowzrocznemu indywidualizmowi. Dużą rolę mogą odegrać pod tym względem religie, które 
formując swych wiernych do pogłębienia duchowości, pomagają im przeciwstawiać się kulturze użycia i kompulsywnej konsumpcji. Ponadto prowadzą one do odejścia od zawężania modelu rozwoju jedynie do płaszczyzny horyzontalnej (ilościowej) i zachęcają do poszerzania modelu rozwoju o płaszczyznę wertykalną (jakościową).

W opinii papieża Franciszka ważną rolę do odegrania w przezwyciężaniu współczesnego kryzysu ekologicznego ma także edukacja ekologiczna. Nie może ona jednak ograniczać się jedynie do sfery informacyjnej, ale powinna uwzględniać krytykę tych wzorców społecznych, które przyczyniają się do niszczenia środowiska. Ponadto edukacja ekologiczna powinna respektować etykę ekologiczną, która dostarczy ludziom głębokich, wewnętrznych i dojrzałych motywacji. Tylko dzięki nim człowiek będzie zdolny do solidarności, odpowiedzialności i troski za całą wspólnotę zamieszkującą obecnie i w przyszłości nasz wspólny dom - Ziemię.

\section{Bibliografia}

Arendt H. 2003. O rewolucji. Warszawa: Czytelnik. Bacon F. 1955. Novum Organum. Warszawa: PWN. Bacon F. 1959. O buntach i zaburzeniach. W F. Bacon. Eseje, tłum. Cz. Znamierowski, 59-68. Warszawa: PWN

Benedykt XVI. 2009. Encyklika Caritas in veritate. O integralnym rozwoju ludzkim w mitości i prawdzie (29 czerwca 2009). Kraków: Wydawnictwo M.
Franciszek (papież). 2015. Encyklika Laudato si'. W trosce o wspólny dom (24 maja 2015). Kraków: Wydawnictwo M.

Jan Paweł II. 1989. Encyklika Sollicitudo rei socialis (30 grudnia 1987). Wrocław: Wrocławska Księgarnia Archidiecezjalna.

Jan Paweł II. 1991. Encyklika Centesimus annus (1 maja 1991). Warszawa: Augustianum.

Jan Paweł II. 2009. Homilia podczas mszy św. dla pracujących na roli. Ziemia jest darem Boga dla wszystkich ludzi (Recife - 7 lipca 1980). W Jan Paweł II. Dzieła zebrane. Homilie i przemówienia z pielgrzymek - Ameryka Pólnocna i Południowa, tom XII, 416-421. Kraków: Wydawnictwo M.

Lorenz K. 1973. Civilized man's eight deadly sins, tłum. M.K. Wilson. New York: Harcourt Brace Jovanovich.

Łepko Z. 2010. „Ekologiczna wymowa dialektyki oświecenia". Studia Ecologiae et Bioethicae, 8(2): 121-135.

Papieska Rada Iustitia et Pax. 2005. Kompendium nauki społecznej Kościoła. Kielce: Jedność.

Paweł VI. 1967. Encyklika o popieraniu rozwoju ludów (26 marca 1967). Kraków: Znak.

Paweł VI. 1970. Przemówienie do FAO z okazji dwudziestej piątej rocznicy powstania (16 listopada 1970).

Schäfer L. 1993. Das Bacon-Projekt. Von der Erkenntnis, Nutzung und Schonung der Natur. Frankfurt am Main: Suhrkamp.

\section{The Influence of Social Phenomenon on the Contemporary Ecological Crisis in the Light of the Encyclical Laudato Si'}

\section{Summary}

In the encyclical Laudato Si'. On Care for our Common Home, Pope Francis sums up the rich legacy of his predecessors contained in the statements on the ecological question. The Pope's standpoint actively involves the community of the Catholic Church into the mainstream of the contemporary environmental debate. It seems, that the Pope designates those social phenomena that have a particularly significant impact on the modern ecological crisis. The most important among them are: the intimate relationship between the poor and the fragility of the planet, the throwaway culture, the new ways of understanding the progress, and the proposal of a new lifestyle.

\section{Key words}

encyclical Laudato Si', religion and ecology, throwaway culture, lifestyle, model of progress 